DOI: 10.1515/LPTS-2015-0011

\title{
NON-CONTACT MEASUREMENT OF THE THICKNESS AND DIELECTRIC PARAMETERS OF DIELECTRIC PLATES AND SHELLS
}

\author{
I. Matiss* \\ Riga Technical University, \\ 1 Kalku Str., Riga LV-1658, LATVIA,
}

Phone: +37167212807, fax:+37167212807, e-mail: certcn@latnet.lv

The paper describes a new approach for non-destructive testing of the structural and geometric parameters of dielectric objects using capacitance techniques. The novelty of this approach lies in the design of a capacitance sensor comprising an array of electrodes with changeable potential distribution on them during a measurement process. This makes solvable the problem of measuring independently three input parameters. To demonstrate the capabilities of the developed measurement algorithms, the case studies based on computer simulation have been carried out.

Keywords: multiparameter measurements, capacitance sensors, dielectric characteristics, computer simulation

\section{INTRODUCTION}

The paper presents a continuation of the research devoted to the multiparameter measurements of geometric and dielectric characteristics using capacitance techniques [1]. The primary principles - particularly, the design of capacitance sensor, the theoretical assumptions, the scanning of a test sample by electric field of variable topography, and the data processing methodology - are identical to those described in the mentioned previous publication. The primary distinguishing feature of the present research is that the dimension of the measurement problem was extended up to three information units, beginning with the input of measurement system and continuing through all the data-handling stages. Detailed investigation into the capabilities of developed measurement algorithms was carried out as case studies based on computer simulation.

\section{METHODS AND PROCEDURES}

The key element of this study is a capacitance sensor, which consists of a number of alternate sign electrodes adapted to the surface of the test sample. The

\footnotetext{
${ }^{1}$ Permanent address: 1 Akademijas laukums, Riga, LV-1050, Latvia, phone/fax +371 67212807, e-mail: certcn@latnet.lv
} 
potential distribution over the electrodes can be altered in accordance with definite algorithms and can thus provide the necessary electric field intensity distribution throughout the test sample. The elaboration of mathematical models of capacitance sensors in the form of electrode array is based on the electromagnetic field theory and methods of mathematical physics, particularly, the potential theory $[1,2]$. Due to the multidimensional nature of the data received from the test object, the handling of such information consists of methods for array processing. For this purpose, the theory of algebraic transformations was applied.

\section{UNDERLYING PRINCIPLES OF THE CAPACITANCE SENSOR MODELLING}

Examples of electrode arrays with variable electric field topography which are intended for tests with unilateral access to the surface of objects are presented in Fig. $1 a$ (shells) and Fig. $1 b$ (plates).

For modelling purposes, the actual design of a unilateral array of electrodes is replaced by a schematic model which contains only one section (shaded in Fig. 1c) in a series of definite number $(n)$ of alternating-sign electrodes [3]. The multi-element system is assumed to comply with the conditions of a plane-parallel electric field in which the capacitance of the sensor is expressed in units of length of straight-line electrodes, for example $[\mathrm{pF} / \mathrm{m}]$.

a)

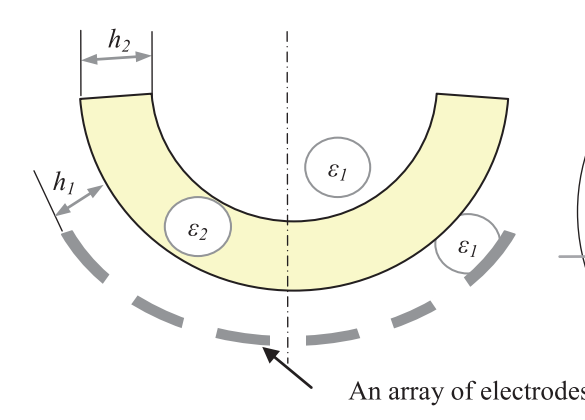

b)

) c)

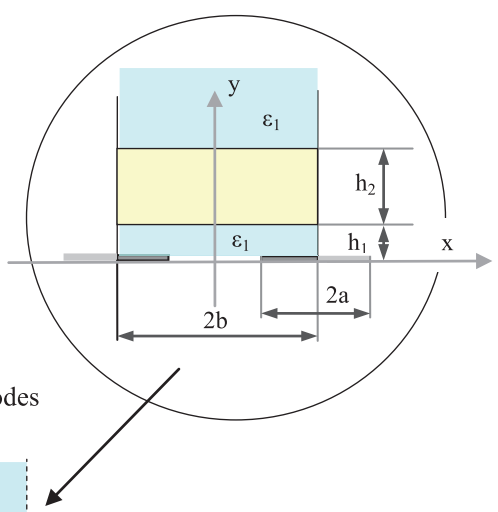

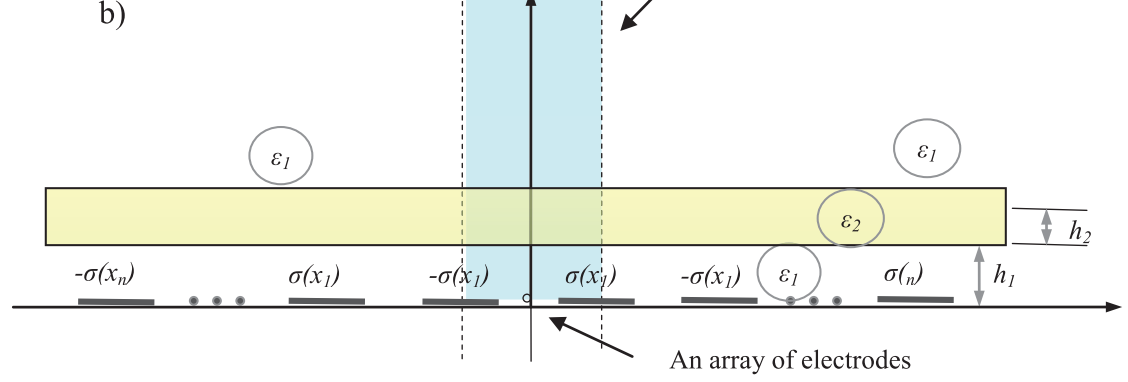

Fig. 1. Schematic design of the electrode arrays for modelling purposes:

a) for shells;

b) for a test object with flat surface;

c) one section of the multi-electrode array. 


\section{JUSTIFICATION OF THE MEASUREMENT PROCEDURE}

The output of the multi-element capacitive sensor is the capacitance expressed as a three-argument function $C_{m}\left(\varepsilon_{2}, h_{2}, h_{1}\right)$, in which the arguments are the input quantities of the measurement system (i.e., the dielectric permittivity $\left(\varepsilon_{2}\right)$, the thickness of test item $\left(h_{2}\right)$, and the clearance between the electrode array and the surface of test item $\left(h_{1}\right)$ ). In accordance with geometric interpretation, the output describes a volume surrounded by a surface (ABCD) within the boundaries of the measurement range in a $3 \mathrm{D}$ space (Fig 2). For example, $C_{l}=$ const representing the dependence $C_{m}\left(\varepsilon_{2}, h_{2}, h_{1}\right)$ is reproduced as a point $\mathrm{M}$ in this space. A solution to the recovering problem in general terms would identify the search entries of a calibrated file in which the corresponding components of the input are equal (Fig. 2):

$$
\varepsilon_{21}=\varepsilon_{22}=\varepsilon_{23} ; \quad h_{11}=h_{12}=h_{13} \text { and } \quad h_{21}=h_{22}=h_{23}
$$

(in Fig. 2 notations $\varepsilon_{23}, h_{13}$ and $h_{23}$ are not shown).

Therefore, to recover the inputs, at an operator's disposal there are measurement results, i.e. three values of capacitance $\left(C_{1 m}, C_{2 m}\right.$ and $\left.C_{3 m}\right)$ and the information collected in advance as 3D calibration data.

In this particular study, evaluation of the recovered input was conducted using the original algorithm already discussed in previous study [1]. This algorithm operates using the data derived through subtracting the measurement readings $\left(C_{m l}\right.$, $C_{m 2}$ and $C_{m 3}$ ) from all entries of the calibrated data file.

Thus obtained data possess some important features. The columns and rows of the derived file hold a change of sign at certain values of the input (hereafter - zero transition functions) and are therefore easily identified.

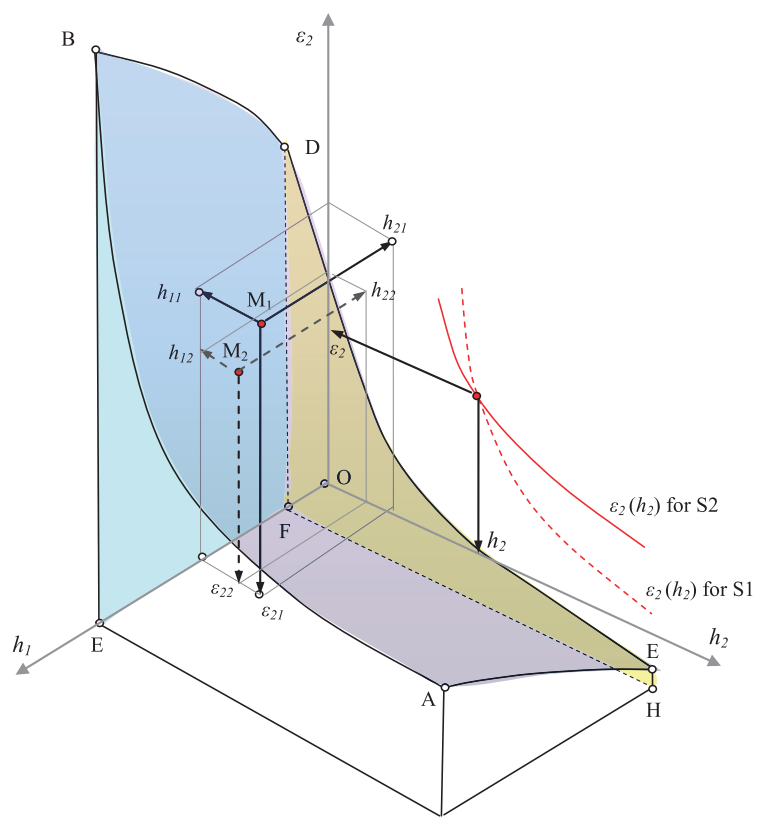

Fig.2. Geometric interpretation of the interrelationship among three input parameters: dielectric permittivity $\left(\varepsilon_{2}\right)$, clearance $\left(h_{1}\right)$ and thickness $\left(h_{2}\right)$ presented in a 3D space; $\varepsilon_{2}\left(h_{2}\right)$ for S1 and $\varepsilon_{2}\left(h_{2}\right)$ for S2 are projections of zero transition functions on the plane $h_{l}=$ const. 


\section{NON-CONTACT MEASUREMENT OF THICKNESS AND DIELECTRIC PERMITTIVITY: A CASE STUDY}

To illustrate details of the algorithm presented above, a case study was performed to characterise a test item using actual geometric dimensions of electrode arrays and specific measurement ranges (Tables 1 and 2). The full measurement procedure, including calibration, was performed using the model described in [1].

Table 1

Potentials of electrodes at symmetrically located sections with dimensions: $a=2 \mathrm{~mm}, b=2.5 \mathrm{~mm}, n=8$ (Fig. 1c)

\begin{tabular}{|c|c|c|c|c|}
\hline $\begin{array}{c}\text { Electrode } \\
\text { array }\end{array}$ & \multicolumn{4}{|c|}{ Potential on electrodes, V } \\
\hline S1 & 1 & 0 & 1 & 0 \\
\hline S2 & 1 & 1 & 1 & 0 \\
\hline S3 & 1 & 0 & 0 & 1 \\
\hline
\end{tabular}

Measurement range and calibration interval of the input parameters

\begin{tabular}{|l|c|c|c|}
\hline \multicolumn{1}{|c|}{ Parameter } & Symbol & $\begin{array}{c}\text { Measurement } \\
\text { range }\end{array}$ & $\begin{array}{c}\text { Calibration } \\
\text { interval }\end{array}$ \\
\hline $\begin{array}{l}\text { Relative dielectric permittivity, } \\
\text { real component (rel. units) }\end{array}$ & $\varepsilon_{2}{ }^{\prime}$ & $3.3-3.7$ & 0.1 \\
\hline $\begin{array}{l}\text { Relative dielectric permittivity, } \\
\text { imaginary component (rel. units) }\end{array}$ & $\varepsilon_{2}{ }^{\prime}$, & $(2.2-4.2) \cdot 10^{-3}$ & $0.2 \cdot 10^{-3}$ \\
\hline Clearance (mm) & $\mathrm{h}_{1}$ & $0.1-0.5$ & 0.05 \\
\hline Thickness (mm) & $\mathrm{h}_{2}$ & $0.4-0.8$ & 0.05 \\
\hline
\end{tabular}

The input quantities (Table 2) are accepted as reference values and used in the measurement procedure, which consists in subjecting the inputs to the entire measurement sequence. The data processing procedure anticipates the selection of one of the inputs as the imposed parameter. The second parameter is determined, and is, therefore, the calculation parameter; the third parameter is the redundant one. This last parameter remains constant for one calculation cycle, which includes scanning the entire set of imposed values. In other words, the input parameters are paired for all combinations of the potential distribution, while the third parameter remains constant. This action is equivalent to projecting a zero transition function on the plane of a constant parameter. As an example, such projections are mapped for $h_{l}=$ const $=0$ in Fig. 2.

To illustrate the behaviour of zero transition functions, actual dependences were modelled for one of the electrode arrays (S1) according to the specifications of Tables 1 and 2. The resultant graphical images are shown in Figs. 3 and 4. 


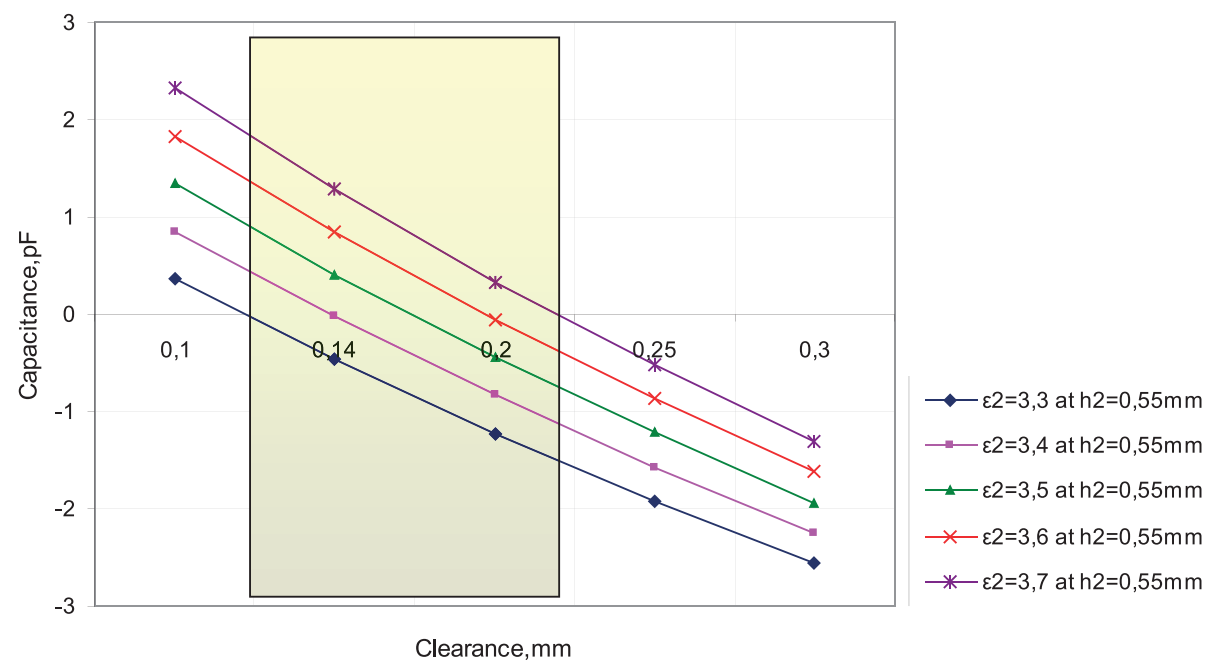

Fig.3. Fragments of S1 transition functions used to determine clearance $h_{r}$. The imposed parameter is $\varepsilon_{2}$, the redundant parameter is $h_{2}=$ const $=0.2 \mathrm{~mm}$, and the reference values are $\varepsilon_{2}{ }^{\prime}=3.684, h_{1}=$ $0.173 \mathrm{~mm}$ and $h_{2}=0.377 \mathrm{~mm}$. The shaded area is the region that was extracted and used to determine the clearance and dielectric permittivity of S1.

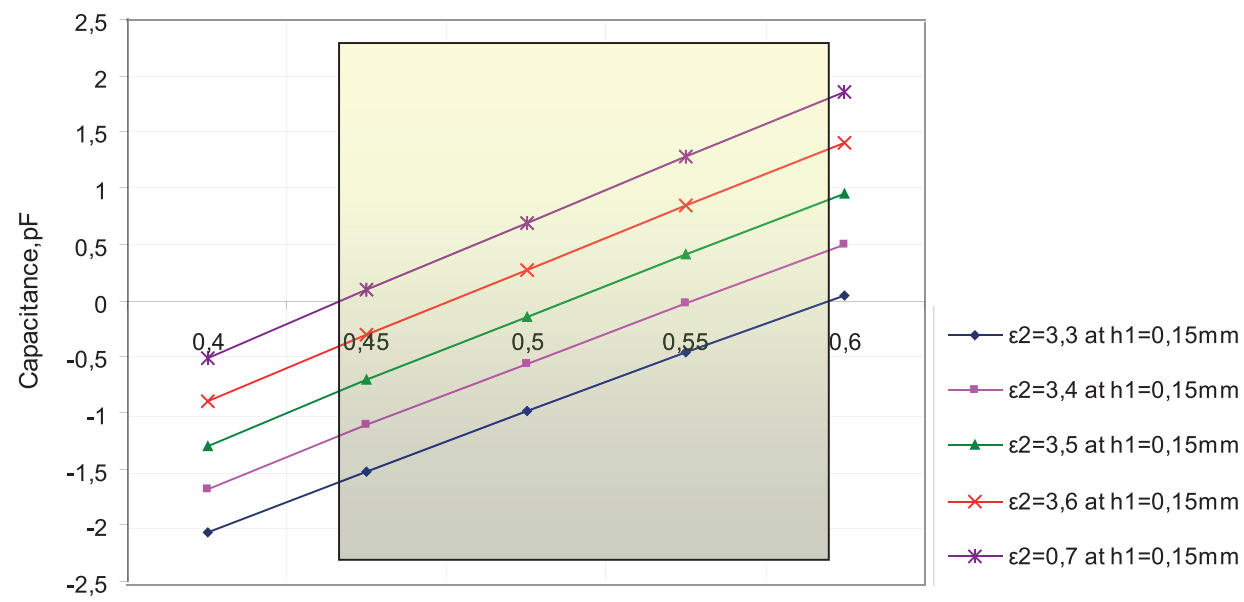

Thickness, $\mathrm{mm}$

Fig.4. Fragments of S1 transition functions used to determine thickness $h_{2}$ The imposed parameter is $\varepsilon_{2}$, the redundant parameter is $h_{1}=$ const $=0.2 \mathrm{~mm}$ and the reference values are $\varepsilon_{2}{ }^{\prime}=3.684, h_{1}=0.173 \mathrm{~mm}$ and $h_{2}=0.377 \mathrm{~mm}$. The shaded area is the region that was extracted and used to determine the thickness and dielectric permittivity of S1.

It should be noted that zero transition functions intersect the abscissa axis at certain points, and each point determines a set of possible input parameters, i.e., clearance $\left(h_{11}\right)$ and thickness $\left(h_{21}\right)$ in Figs. 3 and 4 . The goal of the data processing is to determine the exact coordinates of these points in the whole range of the derived data. These data are utilised to construct the projections of corresponding zero transition functions onto the plane of a constant redundant parameter, e.g. $\varepsilon_{2}\left(h_{2}\right)$ for S1 and $\varepsilon_{2}\left(h_{2}\right)$ for S2 at $h_{1}=$ const in Fig 2. Similar manipulations should be performed for 
other combinations of paired electrode arrays. The intersection points of the projections represent the recovered input of a particular measurement.

Coordinates of the projections of zero transition functions with $\varepsilon_{2}$ 'as the imposed parameter, $h_{1}$ as the calculation parameter and $h_{2}$ as the redundant parameter

\begin{tabular}{|l|l|l|l|l|l|l|}
\hline \multirow{2}{*}{ Sensor } & \multirow{2}{*}{$\begin{array}{l}\text { Geometric pa- } \\
\text { rameter, mm }\end{array}$} & \multicolumn{6}{l}{ Dielectric permittivity, rel. units } \\
\cline { 3 - 7 } & 3.3 & 3.4 & 3.5 & 3.6 & 3.7 \\
\hline \multirow{3}{*}{ S1 } & $h_{1}=0.15$ & 0.1223 & 0.1485 & 0.1740 & 0.1970 & 0.2195 \\
\cline { 2 - 7 } & $h_{2}=0.55$ & 0.5929 & 0.5503 & 0.5111 & 0.4746 & 0.4403 \\
\hline \multirow{3}{*}{ S2 } & $h_{1}=0.15$ & & & 0.1542 & 0.2104 & 0.2642 \\
\cline { 2 - 7 } & $h_{2}=0.55$ & & & 0.5431 & 0.4777 & 0.4165 \\
\hline \multirow{2}{*}{ S3 } & $h_{1}=0.15$ & 0.1519 & 0.1679 & 0.1821 & 0.1948 & 0.2069 \\
\cline { 2 - 7 } & $h_{2}=0.55$ & 0.5450 & 0.5206 & 0.4978 & 0.4767 & 0.4567 \\
\hline
\end{tabular}

To illustrate the applied approach, the calculated coordinates and a graphical representation of the projections for a particular measurement are presented in Table 3 and Fig. 5. The processing technique described to determine the intersection point of the projections is designated hereafter as the curve crossing algorithm.

Figure 5 reveals that the projection curves produced several intersection points depending on the combination of paired electrode arrays. First, this phenomenon may be exploited as a criterion for assessment of the measurement accuracy if the data processing is stopped at this point. Second, this indicates possibilities for enhancement of the data processing algorithm as it makes the solution unclear to some extent, and suggests that the data require further analysis. Such possibilities are clearly illustrated in Fig.6, where the intersection of the curve projections for $h_{l}\left(\varepsilon_{2}{ }^{\prime}\right)$ are plotted for two different values of the redundant parameter.

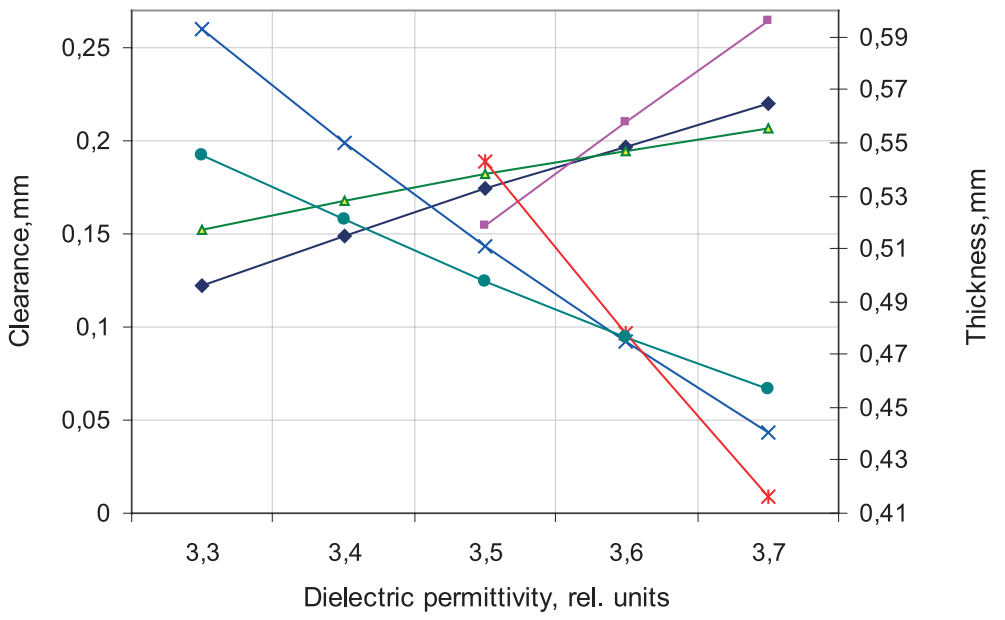

$\longrightarrow \mathrm{S} 1$ at $\mathrm{h} 2=0,55 \mathrm{~mm} \longrightarrow \mathrm{S} 2$ at h2 $=0,55 \mathrm{~mm} \longrightarrow \mathrm{S} 3$ at h2 $=0,55 \mathrm{~mm}$
$\leftarrow \mathrm{S} 1$ at $\mathrm{h} 1=0,15 \mathrm{~mm} \longrightarrow \mathrm{S} 2$ at h1 $=0,15 \mathrm{~mm} \longrightarrow \mathrm{S} 3$ at h1 $=0,15 \mathrm{~mm}$

Fig.5. The projection curves used to calculate the coordinates for $h_{1}\left(\varepsilon_{2}{ }^{\prime}\right)$ the left value axis and for $h_{2}\left(\varepsilon_{2}{ }^{\prime}\right)$ - the right value axis. 


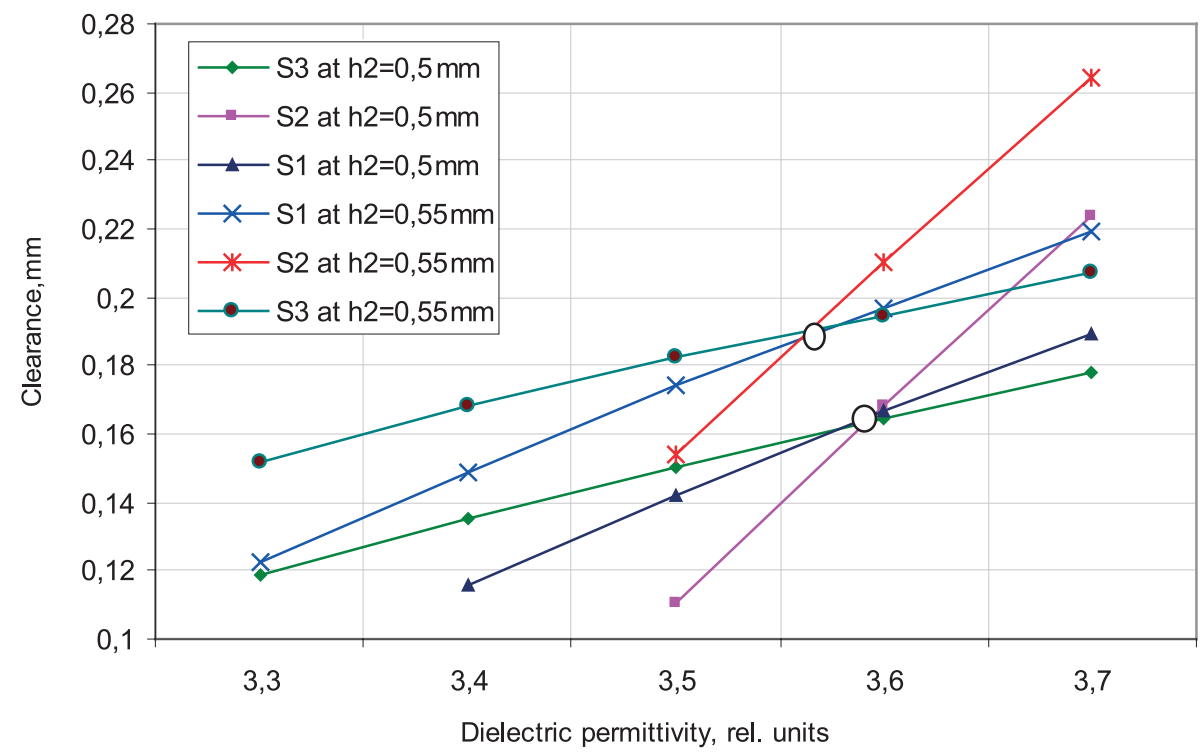

Fig.6. Projections of intersection trajectories with $\varepsilon_{2}$ 'as the imposed parameter, $h_{1}$ as the calculation parameter, and $h_{2}$ as the redundant parameter with $h_{2}=$ const $=0.7 \mathrm{~mm}$ and $h_{2}=$ const $=0.8 \mathrm{~mm}$.

The core of this improvement is in the data handling of the intersection coordinates, which may be considered a second processing step for the previously obtained coordinates. For that reason, the enhanced data processing algorithm is used to determine the crossing of the crossing coordinates (CC algorithm). For the projection curves of $h_{1}\left(\varepsilon_{2}{ }^{\prime}\right)$ shown in Fig. 6 , the dependence is described by a line segment that connects two intersecting points obtained using different values for the redundant parameter $\left(h_{2}\right)$. With known coordinates of the intersection points for both sets of curves, the equations for the first and the second line segments may be written as

$$
h_{11}=k_{1} \varepsilon_{2}+b_{1} \text { and } h_{12}=k_{2} \varepsilon_{2}+b_{2}
$$

where

$$
\begin{aligned}
& k_{1}=\frac{\varepsilon_{21 b}-\varepsilon_{21 a}}{h_{11 b}-h_{11 a}} \text { and } b_{1}=\frac{h_{11 a} \varepsilon_{21 b}-h_{11} \varepsilon_{21 a}}{h_{11 b}-h_{11 a}}, \\
& k_{2}=\frac{\varepsilon_{22 b}-\varepsilon_{22 a}}{h_{12 b}-h_{12 a}} \quad \text { and } \quad b_{2}=\frac{h_{12 a} \varepsilon_{22 b}-h_{12} \varepsilon_{22 a}}{h_{12 b}-h_{12 a}} .
\end{aligned}
$$

with $h_{1 a}, h_{1 b}, h_{1 c}$ and $h_{l d}$ being the initial and the end point coordinates of the abscissa axis for the line segments, while $\varepsilon_{2 a}, \varepsilon_{2 b}, \varepsilon_{2 c}$ and $\varepsilon_{2 d}$ are the initial and the end point coordinates of the ordinate axis for line segments. 
Summary of test results obtained using different algorithms to determine the intersection points for $h_{1}\left(\varepsilon_{2}\right)$ at $h_{2}=$ const

\begin{tabular}{|c|c|c|c|c|c|c|c|c|}
\hline \multirow{2}{*}{ No } & \multirow{2}{*}{$\begin{array}{c}\text { Redundant } \\
\text { parameter, } \\
\text { mm }\end{array}$} & \multirow{2}{*}{$\begin{array}{c}\text { Sensor } \\
\text { array }\end{array}$} & \multicolumn{3}{|c|}{ Recovered output } & \multicolumn{3}{|c|}{ Relative error, $\%$} \\
\hline & & & $\varepsilon_{2}$, rel. units & $h_{1}, \mathrm{~mm}$ & $h_{2}, \mathrm{~mm}$ & $\delta \varepsilon_{2}^{\prime}$ & $\delta h_{1}$ & $\delta h_{2}$ \\
\hline \multicolumn{9}{|c|}{ Real component of dielectric permittivity, rel. units } \\
\hline 1 & \multirow{3}{*}{$h_{2}=0.525$} & $\mathrm{~S} 1 \& \mathrm{~S} 2$ & 3.5772 & 0.1767 & 0.5375 & -0.10 & 2.17 & 3.76 \\
\hline 2 & & $\mathrm{~S} 1 \& \mathrm{~S} 3$ & 3.5820 & 0.1779 & 0.5375 & 0.02 & 2.84 & 3.76 \\
\hline 3 & & $\mathrm{~S} 2 \& \mathrm{~S} 3$ & 3.5784 & 0.1774 & 0.5375 & -0.07 & 2.56 & 3.76 \\
\hline 4 & \multirow{3}{*}{$h_{2}=0.55$} & $\mathrm{~S} 1 \& \mathrm{~S} 2$ & 3.5596 & 0.1878 & 0.5375 & -0.59 & 8.55 & 3.76 \\
\hline 5 & & $\mathrm{~S} 1 \& \mathrm{~S} 3$ & 3.5781 & 0.1920 & 0.5375 & -0.07 & 11.02 & 3.76 \\
\hline 6 & & $\mathrm{~S} 2 \& \mathrm{~S} 3$ & 3.5640 & 0.1902 & 0.5375 & -0.47 & 9.98 & 3.76 \\
\hline 7 & \multirow{3}{*}{$h_{2}=0.716$} & $\mathrm{~S} 1 \& \mathrm{~S} 2$ & 3.6879 & 0.1756 & 0.716 & 0.10 & 1.55 & 0 \\
\hline 8 & & $\mathrm{~S} 1 \& \mathrm{~S} 3$ & 3.6892 & 0.1759 & 0.716 & 0.14 & 1.70 & 0 \\
\hline 9 & & $\mathrm{~S} 2 \& \mathrm{~S} 3$ & 3.6882 & 0.1758 & 0.716 & 0.11 & 1.64 & 0 \\
\hline 10 & CC exp. & $\mathrm{S} 1 \& \mathrm{~S} 2$ & 3.5824 & 0.1743 & 0.5195 & 0.029 & 0.791 & 0.302 \\
\hline 11 & & $\mathrm{~S} 1 \& \mathrm{~S} 3$ & 3.5821 & 0.1766 & 0.5227 & 0.032 & 2.090 & 0.907 \\
\hline 12 & & $\mathrm{~S} 2 \& \mathrm{~S} 3$ & 3.5814 & 0.1755 & 0.5212 & 0.013 & 1.461 & 0.635 \\
\hline \multicolumn{3}{|c|}{ Reference values for $\varepsilon_{2}{ }^{\prime}$} & 3.581 & 0.173 & 0.518 & - & - & - \\
\hline \multicolumn{9}{|c|}{ Imaginary component of dielectric permittivity, rel. units } \\
\hline 11 & \multirow{3}{*}{$h_{2}=0.6$} & $\mathrm{~S} 1 \& \mathrm{~S} 2$ & $6.0806 \cdot 10^{-3}$ & 0.1509 & 0.6 & 1.97 & -12.72 & -16.20 \\
\hline 12 & & $\mathrm{~S} 1 \& \mathrm{~S} 3$ & $6.0000 \cdot 10^{-3}$ & 0.1435 & 0.6 & 0.62 & -16.99 & -16.20 \\
\hline 13 & & $\mathrm{~S} 2 \& \mathrm{~S} 3$ & $6.0596 \cdot 10^{-3}$ & 0.1462 & 0.6 & 1.62 & -15.48 & -16.20 \\
\hline 11 & \multirow{3}{*}{$h_{2}=0.7$} & $\mathrm{~S} 1 \& \mathrm{~S} 2$ & $5.9921 \cdot 10^{-3}$ & 0.1740 & 0.7 & 0.48 & 0.59 & -2.23 \\
\hline 12 & & $\mathrm{~S} 1 \& \mathrm{~S} 3$ & $5.9752 \cdot 10^{-3}$ & 0.1727 & 0.7 & 0.20 & -0.15 & -2.23 \\
\hline 13 & & $\mathrm{~S} 2 \& \mathrm{~S} 3$ & $5.9879 \cdot 10^{-3}$ & 0.1731 & 0.7 & 0.41 & 0.09 & -2.23 \\
\hline \multicolumn{3}{|c|}{ Reference values for $\varepsilon_{2}{ }^{\prime \prime}$} & $5.963 \cdot 10^{-3}$ & 0.173 & 0.716 & - & - & - \\
\hline
\end{tabular}

The coordinates of intersection for the two line segments [4] are given by the recovered outputs of the $\mathrm{CC}$ algorithm as follows.

$$
h_{1 r}=\left|\frac{B_{1} C_{1}}{B_{2} C_{2}}\right| \div\left|\frac{A_{1} B_{1}}{A_{2} B_{2}}\right| \quad \text { and } \quad \varepsilon_{2 r}=\left|\frac{C_{1} A_{1}}{C_{2} A_{2}}\right| \div\left|\frac{A_{1} B_{1}}{A_{2} B_{2}}\right| \text {, }
$$

where the line equations are set in the following form:

$$
A_{1} \varepsilon_{21}+B_{1} h_{11}+C_{1}=0 \text { and } A_{2} \varepsilon_{22}+B_{2} h_{12}+C_{2}=0
$$

Lastly, the condition for the optimal solution, where all of the projection curves intersect at a single point, is given by the following:

$$
\left|\begin{array}{l}
A_{1} B_{1} C_{1} \\
A_{2} B_{2} C_{2} \\
A_{3} B_{3} C_{3}
\end{array}\right|=0 \text { and } A_{3} \varepsilon_{23}+B_{3} h_{13}+C_{3}=0
$$




\section{VALIDATION OF THE MEASUREMENT \\ TECHNIQUES APPLIED IN \\ THE CASE STUDY}

Results obtained using different algorithms were assessed and validated by means of quantitative estimates. The compliance of the recovered values with the corresponding reference inputs were expressed in units of relative measurement error and used as validation criteria. The measurement results and validation outputs of the case study are summarised in Table 4 . To save space, a detailed analysis was only performed for the recovered input that was acquired for $h_{l}\left(\varepsilon_{2}{ }^{\prime}\right)$, where the dielectric permittivity was selected as the imposed parameter and the clearance - as the calculation parameter. Data acquired by the precision algorithm (CC) produced the highest measurement accuracy (Table 4, rows 10-12) compared with the similar estimates of previous experiments.

\section{CONCLUSIONS}

1. Scanning test items with a variable electric field presents new applications for capacitance techniques in the independent and non-destructive control of structural and geometric parameters.

2. From the perspective of the model methodology, there is no difference between the real and imaginary components of the dielectric permittivity. Therefore, a more detailed analysis was only performed for the real component; however, all conclusions acquired from this analysis may also be attributed to the imaginary component.

3. Compared with the geometric parameters, the most consistent parameter in all the test experiments of the recovered output in terms of measurement accuracy was the dielectric permittivity.

4. The multidimensional response of the geometric characteristics was less favourable as to their separation by the curve crossing or CC algorithm.

\section{REFERENCES}

1. Matiss, I. (2014). Multi-element sensor for non-destructive measurement of the dielectric permittivity and thickness of dielectric plates and shells. NDT and E International, 66, 99-105.

2. Armitage D. H., \& Gardiner, S. J. (2001). Classical Potential Theory. Springer, pp. 89-118.

3. Matiss, I. (2011). Electrical Measurement Techniques - a New Challenge for NonDestructive Testing. Publishing House of Riga Technical University, Riga (in Latvian), pp.44-56.

4. Venema, G.A. (2005). The Foundations of Geometry. Prentice Hall, New Jersey, pp. 111-113. 


\section{DIELEKTRISKU PLĀKŠN̦U UN ČAULU BIEZUMA UN DIELEKTRISKO ĪPAŠĪBU BEZKONTAKTA MËRİSANA}

\section{Matīss}

Kopsavilkums

Rakstā aprakstīta jauna pieeja dielektrisku objektu struktūras un geometrisko parametru nesagraujošai testēšanai ar kapacitatīiām metodēm. Jauninājuma būtība ir kapacitatīva sensora konstrukcija, kas sastāv no elektrodu matricas ar iespēju mērī̌sanas procesā izmainīt potenciālu sadalījumu uz šiem elektrodiem. Tas dod iespēju atrisināt problēmu par triju ieejas parametru neatkarīgu mērīšanu.

Ir doti konkrēti testēšanas piemēri izstrādāto mērīšanas algoritmu iespēju demonstrēšanai. Šie piemēri īstenoti ar datormodelēšanas līdzekḷiem.

04.02.2015. 